\title{
Self-regulatory Strategies Used by Malaysian University Students in Reducing Public Speaking Anxiety: A Case Study
}

\author{
Xue Ting Tee ${ }^{1, *}$, Tjin Ai Tan Joanna², Wirawahida Kamarulzaman ${ }^{3}$ \\ ${ }^{1}$ Universiti Tunku Abdul Rahman, Kampar, Perak, Malaysia \\ ${ }^{2}$ Department of Languages and Linguistics, Universiti Tunku Abdul Rahman, Kampar, Perak, Malaysia \\ ${ }^{3}$ Department of Psychology and Counselling, Universiti Tunku Abdul Rahman, Kampar, Perak, Malaysia \\ *Corresponding author. Email: xueting_tee@hotmail.com
}

\begin{abstract}
Despite the increase in the number of Malaysian graduates entering the workforce, they have often been criticized of lacking proper presentation skills and having poor command of the English Language. Public speaking anxiety is believed to be the root of the issues faced by Malaysian graduates. While there is a growing body of literature researching on treatments and instructor techniques, little is known of self-regulatory strategies that Malaysian graduates could employ in actual situations. The recent information provided by the Minister of Higher Education, Datuk Seri Dr. Noraini Ahmad states about 25\% of new graduates will face challenges to be employed within 6 months. Therefore, this paper examines the correlation between English Language proficiency and Public Speaking Anxiety, while investigating self-regulatory strategies used by Malaysian university students in a private university to alleviate the anxiety. Data had been collected for a year by recruiting 65 university students to complete Public Speaking Class Anxiety Scale questionnaire and have group interview. The findings not only reveal $60 \%$ of the participants experience low levels of public speaking anxiety but also the reasons behind those with a high level of Public Speaking Anxiety. On another note, the findings also cite affective as the type of the strategies that Malaysian university students used the most. While more studies are needed, revising the current public speaking course structure, and refining educational pedagogies are essential for lowering the psychological barrier of speaking.
\end{abstract}

Keywords: Public Speaking Anxiety, Self-regulatory strategies, Malaysian university students

\section{INTRODUCTION}

The Malaysian government has made English Language a compulsory subject in its national educational curriculum since the introduction of the Integrated English Language Syllabus for Primary Schools (KBSR) in 1982. Therefore, English is taught in Malaysia from elementary school (7-12 years old), secondary school (13-17 years old), to post-secondary and tertiary education (18 years old and above). Students must attend at least 11 years of formal English courses in schools, excluding preschool. [1]

Despite the English Language's institutionalised status as a second language, students have a weak command of the language. When recent graduates are interviewed by potential employers, they are unable to tie together correct words or convey their thoughts clearly. [2] In recent years, this issue has become increasingly important in the context of graduate unemployment, where poor presentation skills [3] and a lack of English proficiency [4] are contributing reasons in not being hired. Furthermore, Malaysia's jobless rate increased by $5 \%$ in April, affecting over 60,000 Malaysians and marking the highest percentage of unemployment since 1990. [5]

In response to the factors for not hiring, Rahman et al. [3] and Rusreena et al. [4] pointed the factors to anxiety. In fact, anxiety is confirmed as one of the most common issues in speaking classes [6-8] and speaking has always been cited as "most anxietyproducing experience" [9: p.539]. This statement aligned with of Ozturk and Gurbuz [10] conforming 
that speaking is the most anxiety-provoking skill. Despite study efforts [9, 11-19] to investigate authentic self-regulatory mechanisms to reduce public speaking anxiety among university students, most Malaysian graduates still find it challenging to speak English fluently during job interviews. [20] The reasons for such inequity are because there is a limited understanding of university students' autonomies in reducing the fear other than relying on treatments/instructors. Therefore, the objectives of this study were to (1) measure public speaking anxiety levels amongst university students, (2) correlate their English Language proficiency levels with the anxiety scores, and (3) explore selfregulatory strategies that university students use to help reduce their anxiety.

\section{LITERATURE REVIEW}

For more than fifty years, many researchers have attempted to explore the issue of students' language learning anxiety using the Foreign Language Classroom Anxiety Scale [21-23] with academic achievement. Through the utilisation of FLCAS, numerous studies found that second language learning anxiety negatively correlated with academic achievement reflected in the forms of test scores, course grades, and other assessments. [24-26] On the other hand, a large body of research also seeks to understand the causes of second language learning anxiety in the Malaysian context. [27-30] Yet, all the aforementioned studies emphasised teachers' roles/responsibilities to alleviate students' second language learning anxiety. Little is known about how students can self-regulate their learning anxiety, especially speaking anxiety. [14]

Apart from the research on second language learning anxiety related to causes and academic achievement, fewer studies had also highlighted the impact of speaking anxiety on language proficiency. Early research produced conflicting results in investigating the relationship between these two variables. Only one study [31] found a link between anxiety and language proficiency, with the premise that the issue of competition among classmates, as well as classroom teachers' expectations of higherlevel students, played a role while other literature [32-34] reported that speaking anxiety did not have any facilitating or debilitating effects on language proficiency. As a result, the alternative hypothesis hypothesizes that there is a significant relationship between English SPM results and PSCAS scores.

Besides, there is only a study in Malaysia [32], that examines the relationship between anxiety and language proficiency. Also, the relationship between different levels of public speaking anxiety (PSA) and self-regulatory strategies employed by university students has not been explored. To date, Guo et al. [13] conducted a study on students' use of selfregulatory strategies for language learning anxiety. However, in Malaysia, this perspective has yet to be explored. This study attempts to close the gap (i.e. to shed light on a list of self-regulatory strategies that can be adopted explicitly by university students with different levels of public speaking anxiety).

\section{METHODOLOGY}

Using an explanatory sequential mixed-methods approach, this study was conducted in a private university in Peninsular Malaysia. Participants were 65 university students who took a public speaking course in June 2020. These students were enrolled in various degree programs (i.e. education, business, engineering, science, communication, computer science). Participants were selected according to the criteria: (1) The participant passed for SPM English, (2) The participant learnt the English Language as a second language, (3) The participant presented at least three times in the Public Speaking class, (4) English Language was used as the medium of instruction in Public Speaking class. Ethical clearance was sought from the university and permissions were obtained from the Deans, Heads of Department, and lecturers. Before carrying out the research, consent was also obtained from the participants. The data collection took a year from June 2020.

Given the first research objective was to measure public speaking anxiety levels among the university students, the study adopted the Public Speaking Class Anxiety Scale developed by Yaikhong and Usaha. [35] 17 statements were presented along a five-point Likert scale which covered 4 components: fear of negative evaluation, comfort in speaking English, test anxiety, and communication apprehension. Aside from age, year of study, and course of study, students' SPM English results were also sought through the Demographic Information Questionnaire as reflective of their English Language proficiency levels to investigate the relationship between their English SPM results and PSCAS scores. On the other hand, 5 questions were asked during interviews (i.e. the language speaking backgrounds, the strategies they used to alleviate anxiety before, during, and after having a presentation, the reasons for adopting such strategies) to achieve the third research objective. 
The data collected from the responses in the questionnaires were analysed using Statistical Package for the Social Sciences (SPSS) version 20.0. To achieve the first research objective, descriptive statistics in the form of sum scores were used to determine the levels of public speaking anxiety of the participants. According to Yaikhong and Usaha, scores greater than 68 were classified as high anxiety, scores between 68 and 51 as medium anxiety, and scores less than 51 as mild anxiety. [35] Then, Spearman's correlation was used to identify the relationship between students' English SPM results (ordinal data) and their PSCAS scores (continuous data) after ensuring there is a monotonic relationship between the two variables. Lastly, for the third research objective, coding was done using NVivo. Initials codes and themes were identified based on the interview questions and research objectives. Some themes were adopted from Guo et al.'s study (2018), which investigated students' use of self-regulatory strategies for language learning anxiety. The codes were highlighted using NVivo and were grouped as a cluster with specific themes. The themes that were identified are cognitive, management, social, affective, and avoidance strategies.

\section{FINDINGS AND DISCUSSIONS}

A total of 65 respondents participated in the survey, where the Public Speaking Class Anxiety Scale (PSCAS) was distributed to them. 38 experienced low levels of public speaking anxiety, 13 had moderate levels of public speaking anxiety, and 14 had high levels of public speaking anxiety.

Table 1. Participants' level of public speaking anxiety

\begin{tabular}{|l|c|l|l|l|}
\hline $\begin{array}{l}\text { Level of } \\
\text { public } \\
\text { speaking } \\
\text { anxiety }\end{array}$ & $\begin{array}{l}\text { Number of } \\
\text { participants }\end{array}$ & $\begin{array}{l}\text { Min- } \\
\text { Max }\end{array}$ & M & SD \\
\hline Low & 38 & $17-51$ & 42.68 & 6.91 \\
\hline Moderate & 13 & $52-67$ & 53.54 & 0.78 \\
\hline High & 14 & $68-85$ & 68.14 & 0.36 \\
\hline
\end{tabular}

The English results obtained in the SPM examination were then correlated with each dimension (i.e. fear of negative evaluation, comfort in speaking English, test anxiety, communication apprehension) in the PSCAS. There is a significant, moderate, and negative correlation between their English SPM results and fear of negative evaluation $\left(\mathrm{r}_{\mathrm{s}}=-.522, \mathrm{p}=.000\right)$. This indicates that the lower their English language proficiency, the more the fear of being negatively evaluated by others. Also, there is a significant, moderate, and negative correlation between their English SPM results and test anxiety $\left(\mathrm{r}_{\mathrm{s}}\right.$ $=-.536, \mathrm{p}=.000$ ), stating that the lower their English language proficiency, the higher their test anxiety level. Likewise, there is a significant, moderate, and negative correlation between their English SPM results and communication apprehension $\left(\mathrm{r}_{\mathrm{s}}=-.495\right.$, $\mathrm{p}=.000$ ), indicating that the lower their English language proficiency, the more apprehensive they are. However, their English SPM results is found to have a significant, moderate, and positive correlation with comfort in speaking English $\left(\mathrm{r}_{\mathrm{s}}=.548, \mathrm{p}=\right.$ .000 ), showing that the higher their English proficiency level, the more comfortable they speak English.

Table 2. Spearman's Correlation Test for SPM English Results and Each Component in the PSCAS

\begin{tabular}{lllll}
\hline Variables & 1 & 2 & 3 & 4 \\
\hline SPM English & & & & \\
Results & & & & \\
\hline Fear of & - & & & \\
Negative & $.522^{* *}$ & & & \\
Evaluation & & & & \\
\hline Comfort in & .548 & $-.263^{*}$ & & \\
Speaking & & & & \\
English & & & & \\
\hline Test Anxiety & - & $.731^{* *}$ & $-.285^{*}$ & \\
& $.536^{* *}$ & & & \\
\hline Communication & - & $.707^{* *}$ & $-.336^{* *}$ & $.816^{* *}$ \\
Apprehension & $.495^{* *}$ & & \\
\hline$* * \mathrm{p}<.01\left(2-\right.$ tailed); ${ }^{*} \mathrm{p}<.05 ; \mathrm{N}=65$ & &
\end{tabular}

Results obtained from Spearman's correlation test indicated that fear of negative evaluation, test anxiety, and communication apprehension are reasons behind university students with a high level of public speaking anxiety $(\mathrm{M}=68.14)$. The interview data obtained from the university students with a high level of public speaking anxiety further revealed that they would only speak the English Language if other languages were not allowed. This then also pointed to the factor of 'comfort' in speaking English, where students with a high level of public speaking anxiety took these steps " "take deep breaths", "listen to music" or "meditate" to "reduce [their] tension" to self-regulate this situation.

Other than the correlational test, 237 codes were identified after conducting thematic analysis and they were grouped into 5 main themes based on the selfregulatory strategies - affective, social, management, avoidance, and cognitive strategies. Generally, affective strategy recorded 93 codes (e.g., "take deep breaths", "listen to music") - was of the popular use - followed by management (e.g., "practice more", 
"go over the main points"), cognitive (e.g., "visualize me to remain calm", "brainwash myself to do well"), social (e.g., "practice speech with friends", "look at friends or classmates [during presentation]"), and avoidance strategies (e.g., "ignored what was in front", "not look at audience") which reported 55, 42, 27 , and 20 codes, respectively.

Such a finding pertained to the importance of affective strategies in reducing public speaking anxiety, echoing Kondo and Yang's claim [15] that affective filters should be well managed before setting oneself to a speaking task. At the same time, it supports Behnke and Sawyer's Theory of Habituation and Sensitization [26], which encouraged speakers to anticipate more before meeting anxiety-cues. By doing so, the students acknowledge the existence of speaking anxiety before reducing it. [17]

As for management strategy, some of the interviewees planned their speech, controlled their speech pace, and reflected their own mistakes because "[they were] too nervous", they "sometimes [were] blind to [their] own mistakes or flaws". This lent support to the claim made by Guo et al. [13] that students actively engage in monitoring their learning (i.e. reduce their public speaking anxiety). It also substantiated the idea of a goal-directed attentional system. Cognitive strategies such as positive self-talk, visualization, regulating one's perception of performance make the participants feel "calmed" and "motivate [themselves]" to present better. These strategies of positive thinking support Kondo and Yang's study [15] that these strategies are intended to divert attention from the stressful situation to positive and pleasant cues and bring relief to the anxious students.

Apart from Avoidance Approach, the participants utilised the least frequently the social strategy, which relies on peer support. This finding echoed Guo et al.'s findings. [13] Not only did many worried participants lack the courage to use this method [4], but they also showed little initiative to share with their classmates and rarely engaged in collaborative learning with other students. [13] Only 6 participants in the current study would rehearse the speech with their peers, make eye and verbal contact with others to seek social support, and receive peer feedback after the presentation, indicating that in highly competitive educational societies, students may have developed a keen sense of competitiveness rather than collaboration, causing them to hide their weaknesses rather than openly share them with others to seek help or feedback.
Avoidance strategies such as leave the presentation venue before and after the presentation, and avoid eye contact with the audience, were the least-use strategy. This situation indicated that they tended to tackle anxiety-provoking events rather than avoiding them, implying that they are active agents in managing and lowering their public speaking anxiety. However, looking at a different perspective, although the findings echoed much of the previous literature $[13,15]$, the aforementioned avoidance strategies found to be different from the statements in surveys (i.e. FLCAS, PRPSA) adopted by the researchers. This is because the participants in the present study could not avoid from the presentation, which is one of the statements used to assess language learning anxiety, they instead avoided meeting with anxiety cues such as not entering the presentation room before the presentation, built a comfort zone in immediate time such as "[standing] at the side of the stage - nearby the entrance or exit door".

A further analysis highlights that generally, university students who had low and moderate levels of public speaking anxiety adopted affective strategy (e.g., taking deep breaths, holding an object) before and during the presentation, and adopted management strategy (e.g., reflecting their own mistakes) after the presentation. Even though the use of the affective strategies was less evident among students with low anxiety level [13], it may be speculated that participants with a low level of public speaking anxiety gave more emphasis to their emotions and affection that had influenced their performance when they did not face difficulties in speaking English. Adding to the previous, when Spearman's correctional revealed that their English proficiency level increases, their anxiety level decreases, signifying that anxiety cues were the only barriers faced by them when the participants had a better command of English compared to participants who faced a high level of public speaking anxiety. Because most of the participants were good English users, they were better at monitoring their speaking process. They were able to reflect on their own mistakes and recognize their strengths after the presentation.

On the other hand, participants with a high level of public speaking anxiety adopted affective strategy before, during, and after their presentation. Their fear of negative evaluation, test anxiety, and communication apprehension were more intense compared to those of low and moderate anxiety levels. They not only were more sensitive towards anxiety-cues - the stimulus-driven attentional system was activated -but also were easier to be affected by 
incoming stimuli - an increase in initial sensitization. They had no choice but to directly confront the negative emotional arousal that might disrupt their presentation. As such, affective strategy was well used by students who were having high anxiety levels. [13] Since they put more focus on lowering down their affective filters before and during the presentation, they took deep breaths or read jokes after the presentation to get rid of "unnecessary thoughts that made [them] overwhelmed".

\section{CONCLUSIONS}

This study identifies the relationship between English SPM results and PSCAS scores; at the same time, it also investigates self-regulatory strategies used by university students with different anxiety levels in a private university to alleviate public speaking anxiety. The study accepts the alternative hypothesis which hypothesizes that there is a significant relationship between English SPM results and PSCAS scores. While English language proficiency has a significant, moderate, and negative relationship with fear of negative evaluation, test anxiety, and communication apprehension, it also has a significant, moderate, and negative relationship with comfort in speaking English. As discussed earlier, participants with low and moderate levels of public speaking anxiety used affective strategy before and during the presentation, and management strategy after the presentation to reduce their anxiety. Apart from that, those with high levels of public speaking anxiety used affective strategy before, during, and after their presentation.

\section{AUTHORS' CONTRIBUTIONS}

XTT conducted the interviews and surveys, and drafted the manuscript. JTAT assisted in the review of previous studies and the writing of the manuscript. KW was involved in the study's design. The final manuscript was read and approved by all writers.

\section{ACKNOWLEDGMENTS}

The authors would like to to express their gratitude to the UTAR Scientific and Ethical Review Committee for their unwavering support for the conduct of this study. Deep appreciation also goes to the top management of Faculty of Arts and Social Science and Faculty of Creative Industries for their guidance given throughout this study.

\section{REFERENCES}

[1] David AR, Thang SM, Azman H. Accommodating low proficiency ESL students' language learning needs through an online writing support system. Journal of Social Sciences and Humanities. 2015;10(1):118-127. Available from: http://journalarticle.ukm.my/9355/1/118127 LANGUAGE_LEARNING-Rowena.pdf

[2] English proficiency still a big problem for many M'sian grads. The Star Online. 2017 Jan 21:5.

[3] Rahman FA, Mohamed AH, Saidin K, Nasir NSA. Exploring perceptions of employers on communication skills among fresh graduates. Practitioner Research. 2019;1:69-85. Available from:

http://ejournal.uum.edu.my/index.php/pr/article/ view/8192/1188

[4] Rusreena R, Melor Y, Harwati H. Low speaking proficiency among the Malaysian undergraduates: Why and how? In: Persidangan Antarabangsa Sains Sosial dan Kemanusiaan (ICOSH-UKM); 2018 April 23-24; Universiti Kebangsaan Malaysia. Selangor: Universiti Kebangsaan Malaysia; 2018 [cited 2021 October 20]. p. 678-689. Available from: http://conference.kuis.edu.my/pasak3/images/ep rosiding1/PASAK3 2220.pdf

[5] Jaafar, S. S. Malaysia's April unemployment spikes to $5 \%$, the highest in 30 years. The Edge Markets [Internet]. 2020 June 5 [cited 2021 November 10]. Available from https://www.theedgemarkets.com/article/malays ia-unemployment-rate-spiked-5-april

[6] Khairi IA, Nurul LAR. A study on second language speaking anxiety amount UTM students. Degree [dissertation]. Johor: Universiti Teknologi Malaysia; 2010.

[7] Mak B. An exploration of speaking-in-class anxiety with Chinese ESL learners. System. 2011;39:202-214. Available from: https://doi.org/10.1016/j.system.2011.04.002

[8] Nur A, Baso J, Muhammad AR, John ES. English oral communication apprehension in students of Indonesian maritime. International Journal of English Linguistics. 2017;7(4):158165. Available from: http://doi.org/10.5539/ijel.v7n4p158 
[9] Young DJ. An investigation of students' perspectives on anxiety and speaking. Foreign Language Annals. 1990;23(6):539-553. Available from: https://doi.org/10.1111/j.19449720.1990.tb00424.x

[10] Ozturk G, Gurbuz N. Speaking anxiety among Turkish EFL learners: The case at a state university. Journal of Language and Linguistic Studies. 2014;10(1):1-17. Available from: https://www.jlls.org/index.php/jlls/article/view/ $178 / 165$

[11] Alrabai F. A model of foreign language anxiety in the Saudi EFL context. English Language Teaching. 2014;7(7):82-101. Available from: http://dx.doi.org/10.5539/elt.v7n7p82

[12] Cepon S. Teachers' and students' perspectives on the reasons for speaking anxiety in English for specific purposes. Journal of English for Specific Purposes at Tertiary Level. 2016;4(2):184-201. Available from: http://doi.fil.bg.ac.rs/volume.php?pt=journals\&i $\underline{\text { ssue }=\text { esptoday }-2016-4-2 \& \mathrm{i}=3}$

[13] Guo Y, Xu J, Liu X. English Language learners' use of self-regulatory strategies for foreign language anxiety in China. System. 2018;76:4961. Available from: https://doi.org/10.1016/j.system.2018.05.001.

[14] He D. (2017). How to cope with foreign language speaking anxiety effectively? The case of university students in China. Electronic Journal of Foreign Language Teaching. 2017;14(2):159-174. Available from: https://eflt.nus.edu.sg/wpcontent/uploads/2020/09/he.pdf

[15] Kondo DS, Yang YL. Strategies for coping with language anxiety: The case of students of English in Japan. ELT Journal. 2004;58(3):258265. Available from: http://doi.org/10.1093/elt/58.3.258

[16] Lucas J. Communication apprehension in the ESL classroom: Getting our students to talk. Foreign Language Annals. 1984;17(6):593-598. Available from: https://doi.org/10.1111/j.19449720.1984.tb01748.x

[17] Liu M. Anxiety in oral English classrooms: A case study in China. Indonesian Journal of English Language Teaching. 2007;3(1):119137. Available from: http://ojs.atmajaya.ac.id/index.php/ijelt/article/v iew/132

[18] Shabani MB. Levels and sources of language anxiety and fear of negative evaluation among Iranian EFL learners. Theory and Practice in Language Studies. 2012;2(11): 2378-2383. Available from: https://doi.org/10.4304/tpls.2.11.2378-2383

[19] Woodrow, L. Anxiety and speaking English as a second language. RELC Journal. 2006;37:308328. Available from: http://dx.doi.org/10.1177/0033688206071315

[20] Mehar Singh MK, Chuah JSC. Manufacturing industry employers' perception of graduates' English language skills proficiency. International Journal of Applied Linguistics \& English Literature. 2012;1(4):114-124. Available from: https://doi.org/10.7575/ijalel.v.1n.4p.114

[21] Alpert R, Haber RN. Anxiety in academic achievement situations. The Journal of Abnormal and Social Psychology. 1960;61(2):207-215. Available from: http://dx.doi.org/10.1037/h0045464

[22] Dewaele J. The link between foreign language classroom anxiety and psychoticism, extraversion, and neuroticism among adult biand multilinguals. Modern Language Journal. 2013;97(3):1-21. Available from https://doi.org/10.1111/j.1540$\underline{\text { 4781.2013.12036.X }}$

[23] Horwitz EK, Horwitz MB, Cope J. Foreign language classroom anxiety. The Modern Language Journal. 1986;70(2):125-132. Available from: https://doi.org/10.2307/327317

[24] Aida Y. Examination of Horwitz, Horwitz, and Cope's construct of foreign language anxiety: The case of students of Japanese. The Modern Language Journal. 1994;78(2):155-168. Available from: https://doi.org/10.1111/j.15404781.1994.tb02026.x

[25] Hewitt E, Stephenson J. Foreign language anxiety and oral exam performance: A replication of Phillips's MLJ study. The Modern Language Journal. 2012;96(2):170-189. Available from: https://doi.org/10.1111/j.15404781.2011.01174.x

[26] Liu M, Jackson J. An exploration of Chinese EFL learners' unwillingness to communicate 
and foreign language anxiety. The Modern Language Journal. 2008;92(1):71-86. Available from: $\quad$ https://doi.org/10.1111/j.15404781.2008.00687.x

[27] Chan SH, Ain Nadzimah A, Nurkarimah Y. Investigating the construct of anxiety in relation to speaking skills among ESL tertiary learners. 3L: The Southeast Asian Journal of English Language Studies. 2012;18(3):155-166. Available from: http://journalarticle.ukm.my/5567/1/18_3_13_C hanSweeHeng.pdf

[28] Darmi R, Albion P. Exploring language anxiety of Malaysian learners. In: Proceedings of Second Malaysian Postgraduate Conference (MPC); 2012 July 7-9; Bond University. Queensland: University of Southern Queensland; 2012 [cited 2021 November 18]. p. 170-172. Available from: https://core.ac.uk/reader/11049410

[29] Hamzah, M. H. Language anxiety among first year Malay students at the International Islamic College: An investigation of L2 skills, sources of anxiety, and L2 performance. Master [dissertation]. Selangor: International Islamic University Malaysia; 2007. Available from: http://studentrepo.iium.edu.my/bitstream/12345 6789/6631/1/t00011002479MOHDHILMIHAM ZAHP53.7M697L2007_SEC 24.pdf

[30] Latif NAA. A study on English language anxiety among adult learners in Universiti Teknologi Malaysia. Procedia-Social Behavioral Sciences. 2015;208:223-232. Available from: https://doi.org/10.1016/j.sbspro.2015.11.198

[31] Debreli E, Demirkan S. Sources and levels of foreign language speaking anxiety of EFL university students with regard to language proficiency and gender. International Journal of English Language Education. 2015;4(1):49-62. Available from: http://dx.doi.org/10.5296/ijele.v4i1.8715

[32] Alias A, Rashid NAN. The relationship between students' second language learning anxiety and language proficiency. Journal of Counselling and Educational Technology. 2018;1(2):50-58. Available from: https://doi.org/10.32698/0141

[33] Balemir, S. H. The sources of foreign language speaking anxiety and the relationship between proficiency levels and degree of foreign language speaking anxiety. Master [dissertation]. Ankara: Bilkent University; 2009. Available from: http://hdl.handle.net/11693/14917

[34] Cagatay S. Examining EFL students' foreign language speaking anxiety: The case at a Turkish state university. Procedia-Social and Behavioral Sciences. 2015;199:648-656. Available from: https://doi.org/10.1016/j.sbspro.2015.07.594

[35] Yaikhong K, Usaha S. A measure of EFL public speaking class anxiety: Scale development and preliminary validation and reliability. English Language Teaching. 2012;5(12):23-35. Available from https://doi.org/10.5539/elt.v5n12p23 